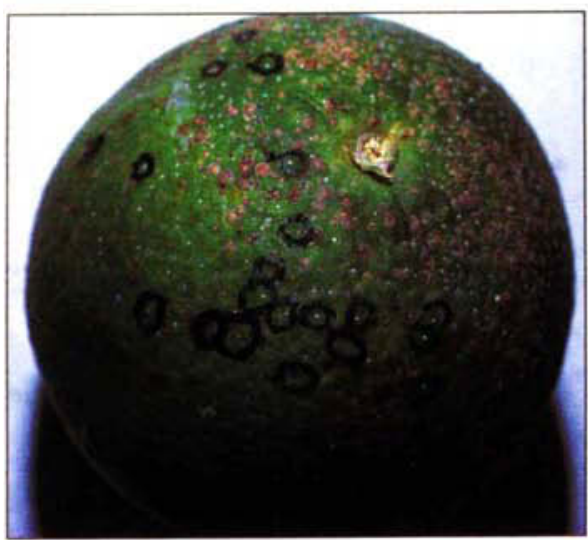

Right, California red scale is a serious citrus pest that causes cosmetic damage and at high levels can limit crop growth. In the fruit-dip bioassay technique, above, used to determine scale resistance to insecticides, scientists circle first-instar scale insects with a black pen and dip the fruit in various concentrations of insecticide.

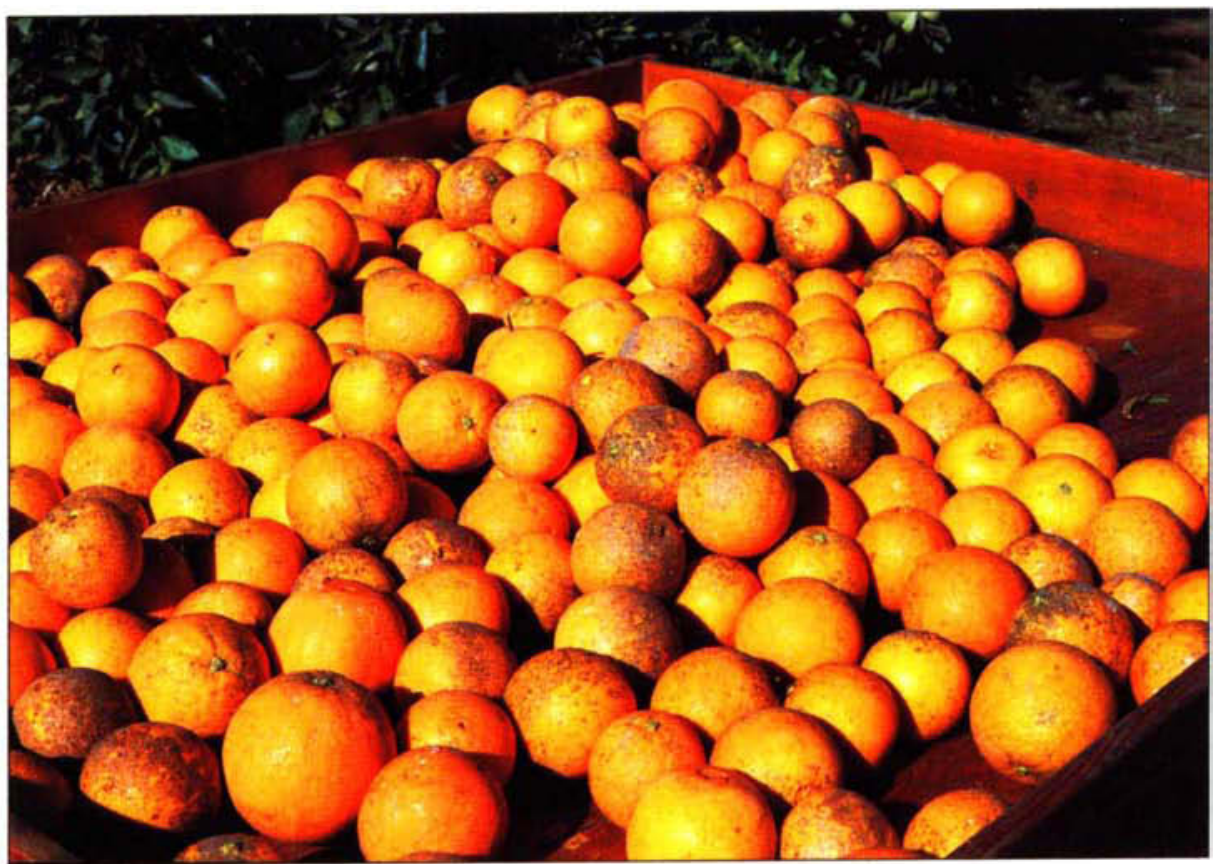

\title{
Armored scale insecticide resistance challenges San Joaquin Valley citrus growers
}

\author{
Elizabeth Grafton-Cardwell $\square$ Yuling Ouyang $\square$ Rebecka Striggow $\square$ Stacy Vehrs
}

\begin{abstract}
Organophosphate and carbamate insecticides have been used to treat citrus pest problems for more than 40 years. From 1990 to 1998, we documented California red scale and yellow scale resistance to these insecticides. Armored scale resistance is found on an estimated $40 \%$ of 163,000 acres of citrus in the San Joaquin Valley. Citrus growers have responded by either increasing their use of natural enemies, especially the parasitoid wasp Aphytis melinus, or by applying newly registered insect growth regulator or neonicotinoid insecticides. While the California red scale problem is, for the moment, greatly reduced, outbreaks of cottony cushion scale are occurring because the new insecticides are highly toxic to the predatory vedalia beetle.
\end{abstract}

C alifornia red scale and yellow scale have been important economic pests in California citrus for more than 80 years. Scale are tiny insects with a dark, circular, waxy covering over their bodies. They live on the twigs and leaves of the plant and the rind of citrus fruit, giving the fruit an unattractive, scaly appearance.

California red scale, Aonidiella aurantii (Maskell), and yellow scale, Aonidiella citrina (Coquillett), cause cosmetic damage to the fruit, resulting in downgrading at the packinghouse. In addition, scale can cause yellow leaves, defoliation, branch dieback and tree death when the pest density is extremely high. In Riverside, Orange, Los Angeles and San Bernardino counties, growers have been very successful in controlling scale with biological control methods (Luck et al. 1986). This is due, in large part, to yearround uniform temperatures, which allow preferred stages of scale to be available for parasitism at all times of the year. Biological control utilizes natural predators of crop pests to limit their growth and spread.

In the San Joaquin Valley, where winter and summer temperatures are more extreme and the pest citrus thrips (Scirtothrips citri) have been controlled by broad-spectrum insecticides, biological control has been more difficult to accomplish. Broad-spectrum insecticides applied for the pest citrus thrips kill the parasitic wasps and predators needed for biological control of scale. Consequently, San Joaquin Valley citrus growers have depended primarily on insecticides to control armored scale.

From the 1950s until the mid- to late 1990s, San Joaquin Valley growers used, almost exclusively, organophosphate and carbamate insecticides to control scale, citrus thrips and most other pests of citrus. In the $1980 \mathrm{~s}$, many populations of citrus thrips became resistant to these insecticides (Morse and Brawner 1986). In the early 1990s, growers noticed that 


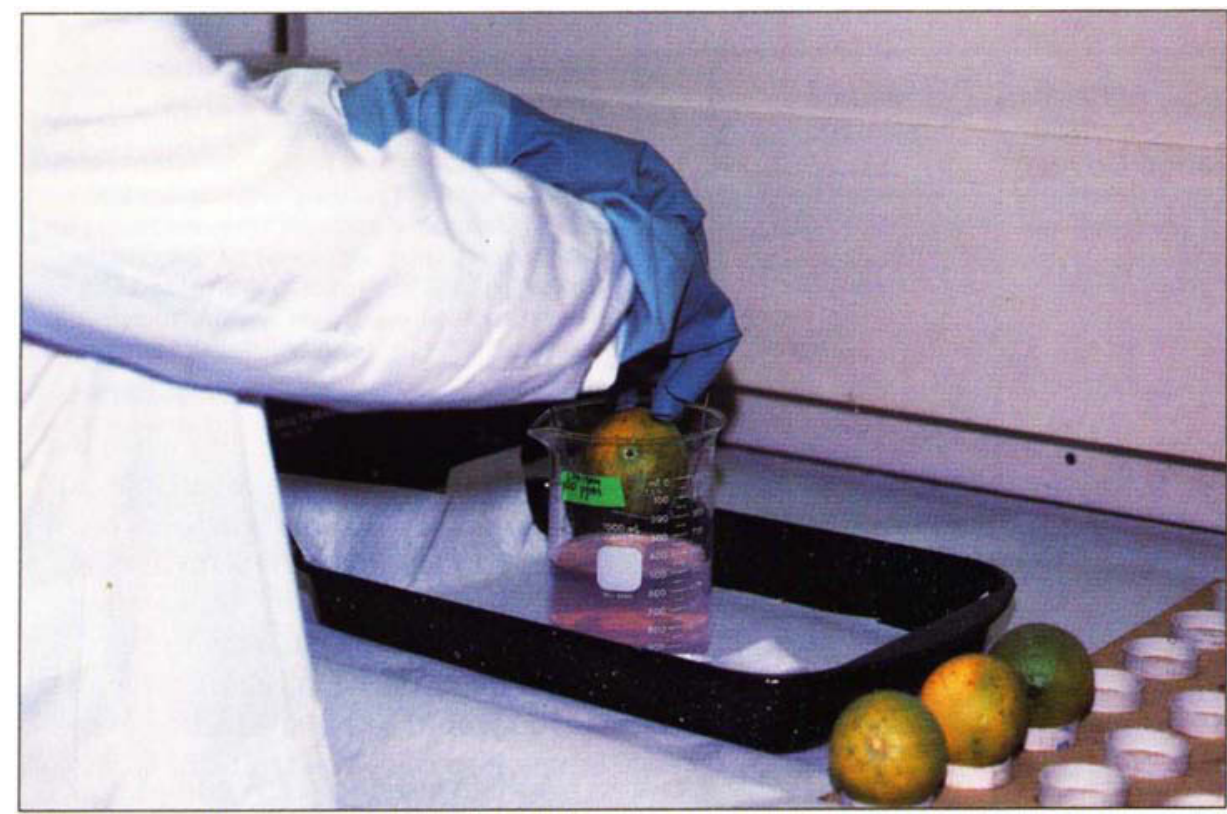

California red scale and yellow scale were becoming more difficult to control. When these pesticides were first introduced, a single application of an organophosphate or carbamate was effective in reducing scale populations for 1 to 2 years. But by the mid-1990s, some citrus growers were spraying three to four applications per year and still not achieving satisfactory control. The increase in insecticide use escalated the economic and environmental costs. At the same time, the marketability of the fruit declined because scale insects were encrusting the fruit.

Armored scale insects have demonstrated their ability to develop resistance to many of the insecticides used to control them. As early as 1912, California red scale resistance to hydrocyanic acid was detected (Quayle 1938). In the 1970s, California red scale populations in some citrus-producing areas of South Africa developed resistance to organophosphate insecticides, including dimethoate, parathion and methidathion, and to a carbamate insecticide, methomyl (Nel et al. 1979).

\section{Insecticide resistance}

Fruit-dip bioassay. In 1990, we began testing armored scale populations from various orchards of the San Joaquin Valley for resistance to two organophosphate insecticides, chlorpyrifos (Lorsban) and methidathion (Supracide), and a carbamate insecti- cide, carbaryl (Sevin). We began our research using a fruit-dip bioassay technique. We circled the first-instar scale (the first stage that settles down and forms a white waxy covering on its back) with a black pen, dipped four to six scale-infested green (underripe) citrus fruit into a specific concentradays to see if the insects were alive or dead (Grafton-Cardwell and Vehrs 1995). We tested each insecticide separately. Because armored scale insects do not move around, it is difficult to tell if they are alive or dead, so we waited 10 days for them to molt into the second instar. Those individuals that molted were considered to be alive and had survived the chemical treatment. We conducted a total of 148 bioassays for methidathion, chlorpyrifos and/or carbaryl resistance from 1990 to 1994 (an average of 30 orchards per year).

We found many populations of scale with resistance to one, two or all three insecticides. Usually, if the scale was resistant to one insecticide, it was at least somewhat resistant to all three (GraftonCardwell and Vehrs 1995). Tests with synergists (chemicals that block the enzymes the insect is using to resist the insecticide) suggested that the insects were using the same mechanism to resist all three pesticides. The same synergist reduced the scale's ability to resist poisoning by all three insecticides; theretion of an insecticide, and waited 10
Using the fruit-dip bioassay technique, scientists found numerous populations of California red scale that were resistant to chlorpyrifos, methidathion and carbaryl.

fore, rotating these insecticides would not reduce resistance.

California red scale. Resistant populations of armored scale were found by our bioassay in most of the citrus-growing region along the foothills of Fresno, Tulare and Kern counties (fig. 1). During the 1950s and 1960s, California red scale eradication districts in Fresno, Tulare and Kern counties used parathion (an organophosphate) to eradicate the pest. After the eradication effort ended in the 1970s, many growers continued to use parathion, as well as chlorpyrifos, methidathion and carbaryl as they became available. With this history of insecticide use, it is not surprising that we found resistant populations in many orchards in the San Joaquin Valley in the 1990s.

Yellow scale. Although yellow scale was less common than California red scale, it seemed to develop a greater frequency or intensity of resistance than red scale. From 1990 to 1994, eight of the 100 orchards tested were infested primarily with yellow scale. All eight populations exhibited resistance to organophosphates and carbamates, and most had high levels of resistance. Knowing that yellow scale had a greater tendency to be resistant to insecticides than California red scale and realizing that yellow scale is more easily controlled with natural enemies, growers with yellow scale rapidly shifted to biological control. Since 1994, it has been difficult to find yellow scale in the San Joaquin Valley.

\section{New colorimetric resistance test}

Mapping resistance using the fruitdip bioassay procedure was problematic. Because the bioassay required a large number of scale-infested green fruit from each orchard, we were limited to orchards with heavy infestations. This biased our sampling toward locations with resistance. We 


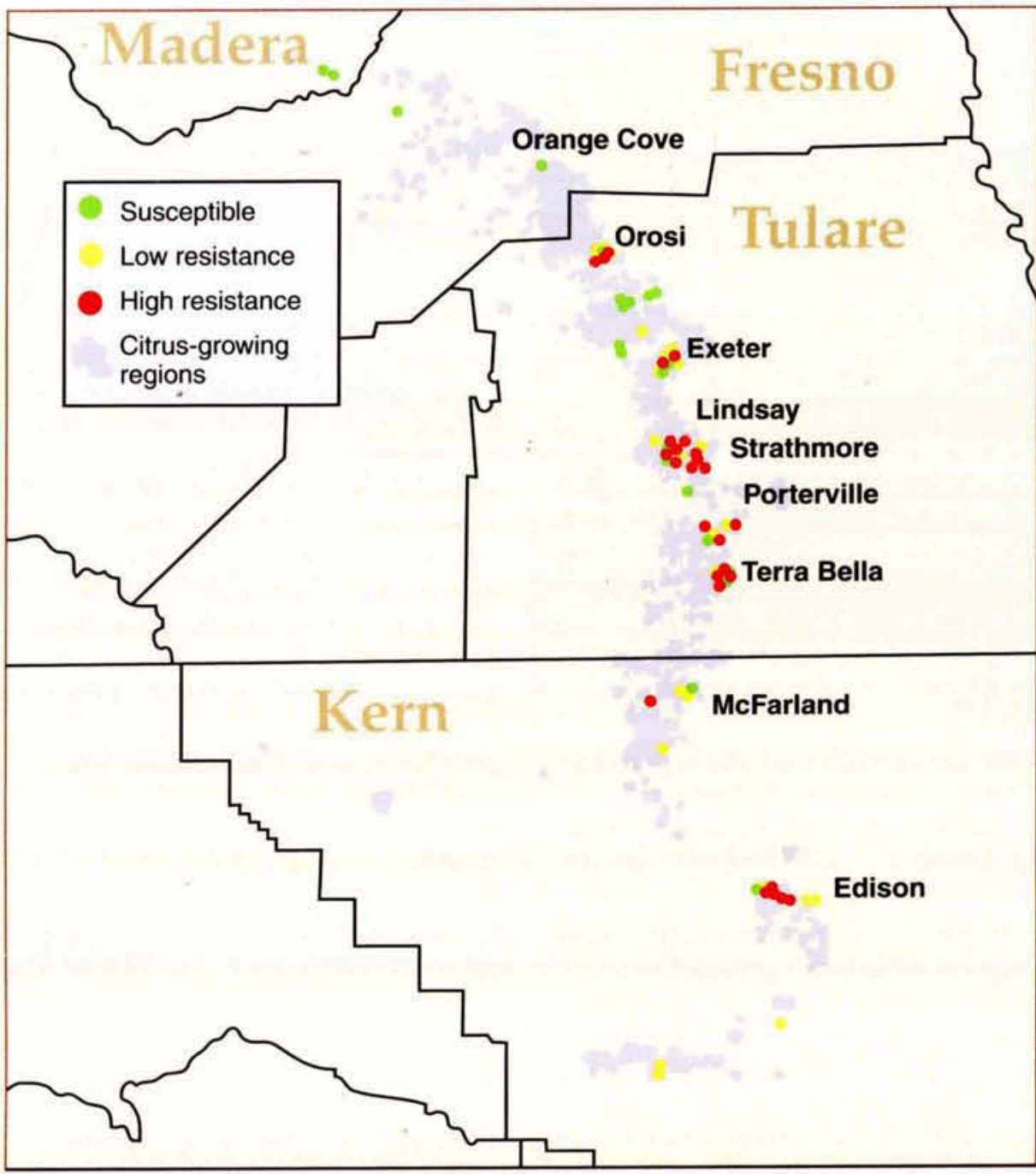

TABLE 1. Number of citrus orchards with organophosphate- or carbamate-resistant California red or yellow scale, based on fruit-dip bioassays* and colorimetric assayst, 1990 to 1998

\begin{tabular}{|c|c|c|c|c|c|}
\hline \multirow[b]{2}{*}{ County } & \multirow[b]{2}{*}{$\begin{array}{c}1998 \\
\text { citrus } \\
\text { acreage }\end{array}$} & \multirow[b]{2}{*}{$\begin{array}{c}\text { Orchards } \\
\text { tested }\end{array}$} & \multicolumn{3}{|c|}{$\begin{array}{l}\text { Number }(\%) \text { of orchards with armored scale } \\
\text { responding with resistance or susceptibility }\end{array}$} \\
\hline & & & $\begin{array}{c}\text { High \% } \\
\text { of resistant } \\
\text { individuals }\end{array}$ & $\begin{array}{l}\text { Low \% } \\
\text { of resistant } \\
\text { individuals }\end{array}$ & Susceptible \\
\hline Madera & 4,337 & 9 & 0 & $1(11 \%)$ & $8(89 \%)$ \\
\hline Fresno & 29,421 & 22 & $9(41 \%)$ & $6(27 \%)$ & $7(32 \%)$ \\
\hline Tulare & 82,875 & 252 & $116(46 \%)$ & $81(32 \%)$ & $55(22 \%)$ \\
\hline Kern & 46,505 & 89 & $25(28 \%)$ & $20(23 \%)$ & $44(49 \%)$ \\
\hline $\begin{array}{l}\text { San Joaquin } \\
\text { Valley total }\end{array}$ & 163,138 & 372 & $150(40 \%)$ & $108(29 \%)$ & $114(31 \%)$ \\
\hline
\end{tabular}

- Standard fruit-dip bioassay for resistance: High resistance is $45 \%$ or less mortality, low resistance is between $46 \%$ and $80 \%$ mortality, and susceptible is $81 \%$ or greater mortality of a scale population. These were measured at discriminating concentrations of chlorpyrifos ( 10 parts per million [ppm]), methidathion (31.6 ppm) or carbaryl (1,000 ppm). Each insecticide was tested separately, but the resistance frequency of the population was defined based on the insecticide it showed the greatest resistance to

†Colorimetric esterase assay for resistance: High resistance is greater than $50 \%$, low resistance is $1 \%$ to $49 \%$, and susceptible is $0 \%$ scale individuals with 0.5 Nmoles or more esterase activity per microgram body weight/minute.
Fig. 1. San Joaquin Valley citrus distribution of insecticide susceptible (81\% to $100 \%$ mortality), slightly resistant ( $46 \%$ to $80 \%$ mortality) and highly resistant ( $45 \%$ or less mortality) armored scale, 19901994. Resistant populations of armored scale were found in most of the citrusgrowing regions tested. We tested the resistance to chlorpyrifos, methidathion and carbaryl using a fruit-dip bioassay.

were also limited to testing when the scale-infested fruit was available, August through October. Growers often sprayed their orchards with insecticides from May to July, so we often could not use the bioassay to help them make decisions about which pesticide would be most effective in the current season. The fruit-dip bioassay requires $\mathbf{1 0}$ days to determine results, giving growers a very slow response time.

In 1995 we began to develop a rapid biochemical test for detecting insecticide-resistant scale. Our research with synergists and electrophoresis demonstrated that resistant California red scale survived the insecticide sprays by using esterase enzymes to bind and detoxify the insecticides entering their bodies (Grafton-Cardwell et al. 1998). In electrophoresis, an electrical current is used to sort enzymes in the ground-up insect. We adapted a colorimetric test used for detecting insecticide resistance in mosquitoes, in which the chemicals in the dish react with esterase enzymes in the crushed body of the insect (Dary et al. 1990).

We placed a portion of a crushed third-instar female scale in each test well of a microtiter plate. This plate has a reader that measures the optical density (color) of the fluid in the plate wells. We used known amounts of alpha naphthol (chemical standard) to estimate the levels of esterase enzymes in the test insects. We found that resistant scale had higher esterase enzyme levels; the liquid in the wells of the plate turned darker for insecticide-resistant scale than susceptible scale.

This new method allowed us to test individual third-instar female scale during more months of the year and from any part of the tree, broadening the types of orchards we could sample. This method also required 
only 1 day to complete, so test results could be returned to the grower quickly. From 1995 to 1997 we were able to conduct 280 tests of scale using the colorimetric test and increase our testing from 30 bioassays per year to nearly 100 . We also tested 34 of these scale populations with chlorpyrifos and methidathion in the standard fruit-dipping method to verify the colorimetric test's reliability. The tests disagreed with each other in only two cases, resulting in $94 \%$ agreement. (We didn't expect the two tests to agree perfectly, because we were testing different scale individuals and different stages of scale with the two bioassay methods.)

Combining data from the fruit-dip bioassay and the colorimetric test for 1990 to 1998 , the highest percentage of orchards with resistant scale occurred in Tulare, which had the greatest citrus acreage, followed by Fresno, Kern and Madera counties (table 1). While our sampling is somewhat biased toward orchards with resistance problems, we estimate that $40 \%$ of the 163,000 acres of citrus in the San Joaquin Valley have armored scale populations with some level of resistance to chlorpyrifos, methidathion and/or carbaryl. When a California red scale population has a high percentage of resistant individuals (45\% or less mortality), insecticide control using these pesticides lasts for no more than 30 days (Vehrs and Grafton-Cardwell 1994), which is less than or equal to the duration of one scale generation. If the insecticide is effective for only 30 days, the grower is forced to spray repeatedly for each of the four scale generations.

Treatment costs. Armored scale insecticide applications in citrus are extremely expensive compared with other pest control methods (Haney et al. 1992). Insecticides targeted to armored scale must be applied in large volumes of water (750 to 2,000 gallons per acre) to penetrate the foliage and move the insecticide to the insect pest. In addition, the spray-rig speed must be very slow, 1.5 miles per hour. If it is any faster, the leaves form a sheet and prevent penetration of the pesticide. The application cost averages $\$ 90$ per

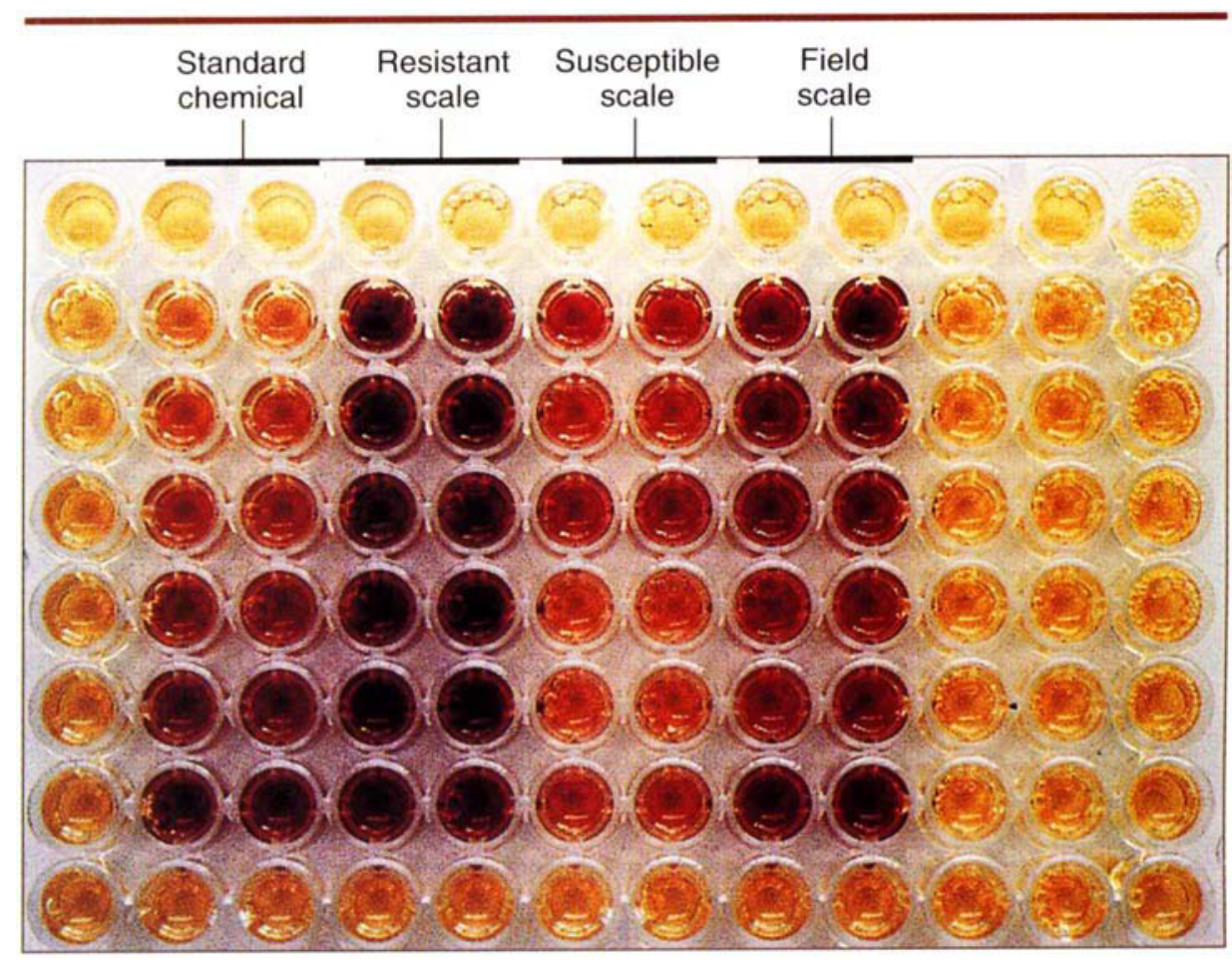

A new colorimetric test for armored scale resistance can obtain results in 1 day, as opposed to $\mathbf{1 0}$ days for the fruit-dip bioassay.

acre for a 1,500 -gallon-per-acre $(\$ 0.60$ per gallon of water), 1.5 -mile-per-hour spray application. The cost of the pesticide is $\$ 65$ to $\$ 75$ per acre. The full cost of one armored scale spray averages $\$ 160$ per acre. In areas where resistance was a serious problem between 1995 and 1997, growers applied insecticides three times each season. In some orchards, scale control alone was costing $\$ 480$ an acre, making citrus growing highly unprofitable.

Spreading resistance. When our resistance monitoring was first initiated in 1990, resistance appeared to be patchy. In 1996 we tested scale from each of 30 citrus orchards within a 1-mile-by-1-mile section of cropland in Tulare County (fig. 2). This section was farmed by eight growers who used different pest management practices through the years and farmed other crops in addition to citrus. The purpose of the test was to determine if resistance was unique to one or more growers or was becoming an areawide problem. We found that scale in every orchard tested showed at least a low percentage of resistant individuals (a minimum of $13 \%$ ) and that some orchards had $100 \%$ resistant individuals. In addition, we found that young blocks bearing fruit for the first time had resistant scale ( $31 \%$ to $40 \%$ ).

Because we found that resistance was becoming a uniform problem in this region, we designated it a "hot spot." Hot spots have been found in Fresno County (Orange Cove), Tulare County (Orosi, Exeter, Lindsay, Strathmore, Porterville and Terra Bella) and Kern County (McFarland and Edison) (fig. 1). Other hot spots may exist that have not yet been detected. The new biochemical colorimetric technique helped us better define regions of greatest scale resistance so we could help growers make the decision to stop the use of organophosphate and carbamate insecticides.

\section{Grower response to resistance}

As a result of the high cost of pesticide resistance in armored scale, dozens of citrus growers began to increasingly rely on biological control. These growers release the parasitoid wasp Aphytis melinus DeBach and protect other natural pest enemies such as the parasitoid wasp Comperiella bifasciata (Howard), predatory beetles and lacewings. The registration of the selective insecticides abamectin (AgriMek) and spinosad (Success) in the 


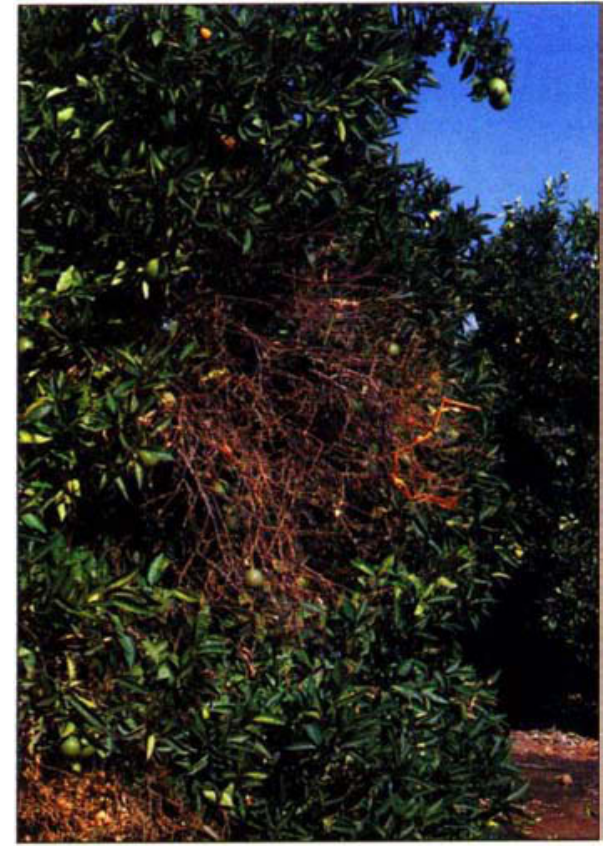

Although armored scale damage to citrus fruit is primarily cosmetic, severe infestations can damage trees and cause branch dieback. Growers increasingly rely on natural enemies to control scale, including parasitic wasps, predatory beetles and lacewings.

late 1990s for the control of citrus thrips helped reduce the broadspectrum organophosphate, carbamate and pyrethroid residues that are toxic to the natural enemies of scale. New high-pressure washers in most packinghouses in the San Joaquin Valley also helped to disinfest scale-infested fruit at the end of the season (Walker et al. 1996).

Even when growers reduce or eliminate broad-spectrum pesticides, these orchards still have their share of problems. Several pests with few options for biological control in the San Joaquin Valley, which were previously easily controlled by organophosphates and carbamates, have become serious problems. These include katydid and citricola scale. However, because many of the natural enemies of scale now have some resistance to organophosphates, growers have found that they can occasionally use low rates of chlorpyrifos for katydid and/or citricola scale control and only mildly disrupt biological control of scale.

New insecticides. Other growers believe that the registration of new insecticides could provide a solution to the organophosphate and carbamate insecticide resistance problem. Several insecticides have been registered or are nearing registration for scale control in California citrus. Pyriproxifen (Esteem) is an insect growth regulator registered in 2000 that mimics juvenile hormones. Buprofezin (Applaud) is an unregistered insect growth regulator that inhibits chitin synthesis. Both of these insecticides inhibit the scale's ability to molt, thereby preventing further growth. The soil-applied formulation of imidacloprid (Admire), registered in 2001, is a neonicotinoid that inhibits scale's ability to feed. These new insecticides could help slow resistance to organophosphates and carbamates, increase worker safety, reduce armored scale densities, improve tree health, and increase fruit marketability.

Field efficacy data for these new products (Grafton-Cardwell and Reagan 1995, 1998), as well as our data documenting the extent of organophosphate resistance, helped the citrus industry obtain an "emergency" Section 18 registration to apply pyriproxifen and buprofezin in Fresno, Tulare and Kern counties in 1998 and 1999. Federal Section 18 registrations allow growers to use an unregistered chemical for specific uses that are deemed critical. Growers requested two pesticides so they could rotate insecticides from different chemical classes and delay the development of resistance in scale insects. The introduction of these insecticides resulted in a $71 \%$ reduction of organophosphate and carbamate use in citrus between 1997 and 1999. The reduction totaled more than 700,000 pounds of pesticide active ingredient per year.

Insecticide drawbacks. While many San Joaquin Valley growers looked to insect growth regulator and neonicotinoid insecticides as a solution to their organophosphate and carbamate resistance problems, use of these newer insecticides has its drawbacks. Sweetpotato whitefly in Israel has begun to develop resistance to both pyriproxifen and buprofezin in cotton despite the implementation of a resistance management program (Horowitz and Ishaaya 1994). Resis- tance to pyriproxifen in California red scale in South Africa is suspected. We expect California red scale in San Joaquin Valley to develop resistance to pyriproxifen and buprofezin fairly rapidly, within 5 to 10 years. Resistance to imidacloprid in armored scale is also likely to develop.

Furthermore, nearly every new insecticide has an impact on one or more natural enemies when it is first introduced. Pyriproxifen, buprofezin and imidacloprid are highly toxic to predatory beetles (Grafton-Cardwell 2000, in press, unpublished data). In some crops this is not a concern, because beetles do not play an important role in pest management. In citrus, however, the vedalia beetle (Rodolia cardinalis) has been controlling cottony cushion scale for nearly 100 years. When insecticides such as DDT and organophosphates were first introduced in the 1940s and 1950s, vedalia beetle was eliminated and cottony cushion scale outbreaks occurred in a number of orchards.

Unhappily, the San Joaquin Valley is experiencing the loss of vedalia beetle again because the beetles are highly sensitive to insect growth regulators and neonicotinoids (Grafton-

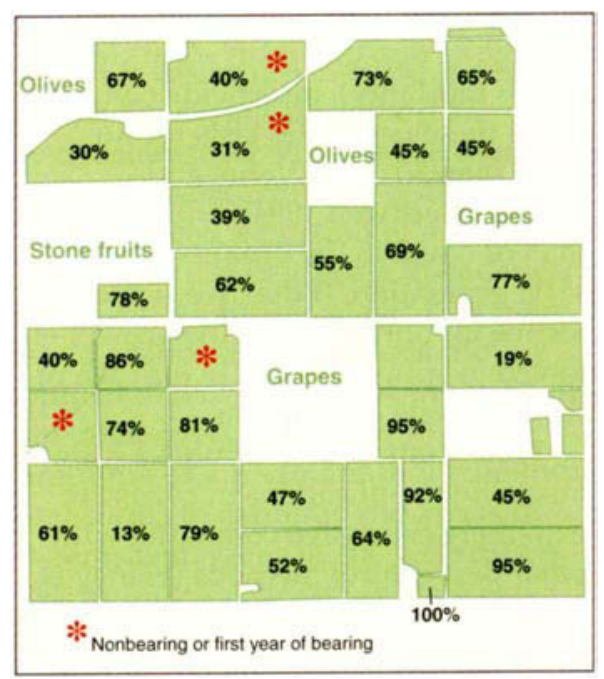

Fig. 2. Percentage of resistant California red scale individuals in $\mathbf{3 0}$ citrus orchards in a 1-mile-by-1-mile section of cropland; this area was designated a "hotspot" for scale resistance. Percentage resistance is based on the colorimetric test that detects individuals with 0.5 nanomoles or more of esterase activity per microgram body weight/minute. 


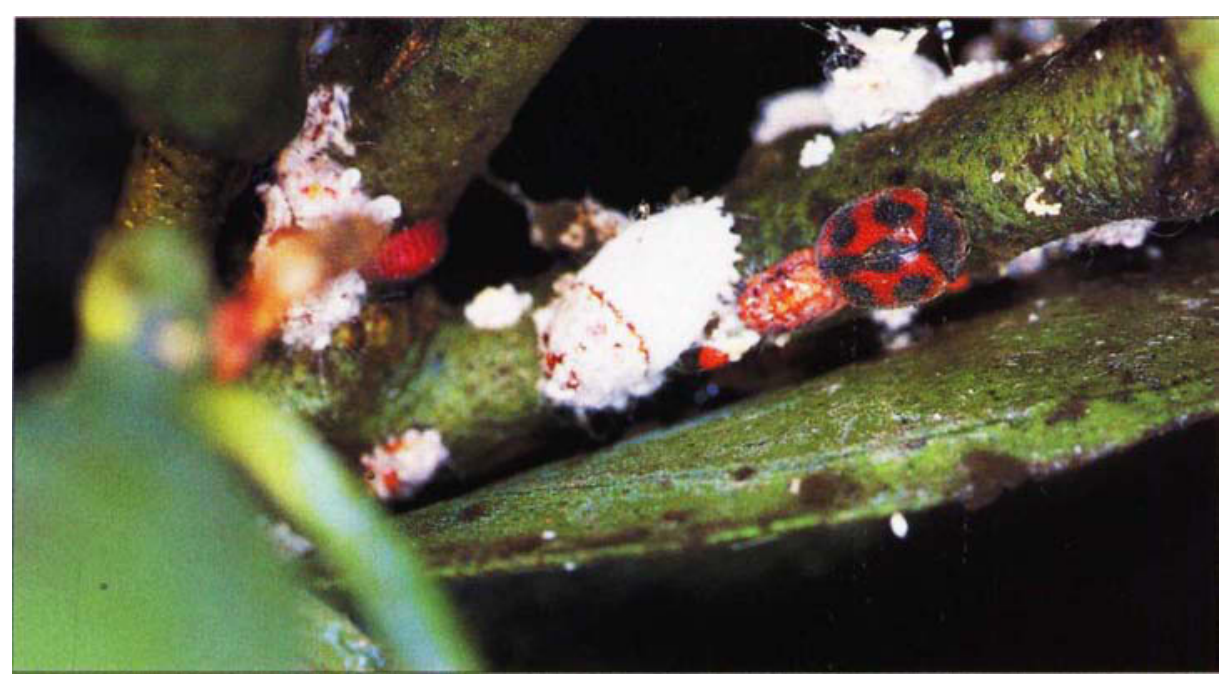

The vedalia beetle feeds on cottony cushion scale. The beetle is highly susceptible to new insect growth regulators and neonicotinoid insecticides registered to control armored scale. As a result, outbreaks of cottony cushion scale have occurred in the San Joaquin Valley.

Cardwell 2000). Growers hadn't seen much of cottony cushion scale in recent years, so they didn't remember how bad it could be.

In the case of pyriproxifen, the beetle is sensitive for several miles around spray areas. When growers first began to use this insecticide in citrus in 1998, vedalia beetles disappeared from all San Joaquin Valley citrus orchards for 9 months. The result was dozens of cottony cushion scale outbreaks that could be controlled only with malathion or methidathion, two organophosphates that are highly toxic to parasites needed to control armored scale. Problems with cottony cushion scale have decreased since 1998 and 1999, probably because less acreage is being treated and the beetles seem to be less sensitive to pyriproxifen than they were the first year. However, cottony cushion scale will continue to plague citrus growers as the use of pyriproxifen, buprofezin and imidacloprid continues (GraftonCardwell in press).

\section{Resistance and pest control}

Because of pesticide resistance and secondary pest outbreaks, new insecticides will be only a temporary solution to the armored scale problem in San Joaquin Valley citrus. Greater reliance on biological control and other nonchemical methods will be necessary for long-term control of citrus pests. California red scale can be suc- cessfully managed using both natural and augmentatively released natural enemies (Haney et al. 1992). However, there will always be destructive native citrus pests, such as katydids and citricola scale that lack effective biological control. In addition, newly introduced pests such as glassy-winged sharpshooter and citrus peelminer that do not yet have adequate biological control will probably require insecticide treatments.

The ongoing challenge for the UC integrated pest management program will be to understand the impact of new insecticides on both pests and natural enemies, rotate insecticide chemistries to forestall resistance, use insecticides in ways that do not seriously disrupt key natural enemies, and develop biological control and nonchemical solutions to myriad interrelated citrus pests.

\section{E. Grafton-Cardwell is IPM Specialist and} Research Entomologist, Department of Entomology, UC Riverside, stationed at UC Kearney Agricultural Center; Y. Onyang is Staff Research Associate, R. Striggow is Laboratory Assistant and S. Vehrs, now a Porterville high school science teacher, is former Staff Research Associate, UC Kearney Agricultural Center. This project was supported by finds from the Citrus Research Board. The authors thank the many growers and pest control advisors who helped identify scale-infested citrus orchards.

\section{References}

Dary O, Georghiou GP, Parsons E, Pasteur N. 1990. Microplate adaptation of Gomeri's assay for quantitative determination of general esterase activity in single insects. $J$ Econ Entomol 83:2187-92.

Grafton-Cardwell EE. 2000. Citrus: Integrating biological control and insecticide treatments for cottony cushion scale and other scale pests. In: Hoddle MS (ed.). Proc of California Conference on Biological Control; July 11-12, 2000; Riverside. p 47-50.

Grafton-Cardwell EE. In press. Citrus IPM in California: Regional differences and their effects on arthropod management in the millennium. Proc of International Society of Citriculture, 9th Int Citrus Congress; December 3-7, 2000. Orlando, FL.

Grafton-Cardwell EE, Ouyang Y, Salse J. 1998. Insecticide resistance and esterase enzyme variation in the California red scale (Homoptera: Diaspididae). J Econ Entomol 91:812-9.

Grafton-Cardwell EE, Reagan CA. 1995 Selective use of insecticides for control of armored scale (Homoptera: Diaspididae) in San Joaquin Valley California citrus. J Econ Entomol 88:1717-25.

Grafton-Cardwell EE, Reagan CA. 1998. California red scale insecticide efficacy trial, 1996. Arthropod Manag Tests 23:62-3.

Grafton-Cardwell EE, Vehrs SLC. 1995.

Monitoring for organophosphate- and carbamate-resistant armored scale in San Joaquin Valley citrus. J Econ Entomol 88:495-504.

Haney PB, Morse JG, Luck RF, et al. 1992. Reducing insecticide use and energy costs in citrus pest management. UC IPM Pub 15, Statewide IPM Project, UC DANR, Oakland, CA. 62 p.

Horowitz AR, Ishaaya I. 1994. Managing resistance to insect growth regulators in the sweetpotato whitefly (Homoptera:

Aleyrodidae). J Econ Entomol 87:866-71.

Luck RF, Morse JG, Moreno DS. 1986. Current status of integrated pest management in California citrus groves. In: Cavalloro $R$, Di Martino E (eds.). Integrated Pest Control in Citrus Groves, Proc of Experts' Meeting; Mar 26-29, 1985; Acireale, Italy. Boston, MA: AA Balkema. p 533-44.

Morse JG, Brawner OL. 1986. Toxicity of pesticides to Scirtothrips citri (Thysanoptera: Thripidae) and implications to resistance management. J Econ Entomol 79:565-70.

Nel JJC, De Lange L, van Ark H. 1979. Resistance of citrus red scale, Aonidiella aurantii (Mask.), to insecticides. J Entomol Soc South Afr 42:275-81.

Quayle HJ. 1938. The development of re sistance to hydrocyanic acid in certain scale insects. Hilgardia 11:183-210.

Vehrs SLC, Grafton-Cardwell EE. 1994. Chlorpyrifos effect on armored scale (Homoptera: Diaspididae) populations in San Joaquin Valley citrus. J Econ Entomol 87:1046-57

Walker GP, Morse JG, Arpaia ML. 1996. Evaluation of a high-pressure washer for postharvest removal of California red scale. J Econ Entomol 89:148-55. 